\title{
To Assess the Performance of Wheat Varieties under Various Fertility Levels
}

\author{
Rai Anil Kumar ${ }^{1}$, Sunil Kumar Jatav ${ }^{2 *}$ and J.P. Dixit ${ }^{1}$ \\ ${ }^{1}$ Department of Agronomy, Collage of Agriculture, Rajmata Vijayaraje Scindia Krishi Vishwa \\ Vidhyalaya, Gwalior, 474220 (M. P.), India \\ ${ }^{2}$ Krishi Vigyan Kendra, Balaghat, Madhya Pradesh, India \\ *Corresponding author
}

\begin{tabular}{l} 
Ke y w o r d s \\
$\begin{array}{l}\text { Triticum aestivum L., } \\
\text { Varieties, Fertility }\end{array}$ \\
Article Info \\
$\begin{array}{l}\text { Accepted: } \\
15 \text { September } 2018 \\
\text { Available Online: } \\
10 \text { October } 2018\end{array}$ \\
\hline
\end{tabular}

A field experiment was laid out at Research Farm, College of Agriculture, Gwalior, during Rabi season (2014-15) to study of performance of wheat varieties under various fertility levels. The experiment was conducted in Factorial Randomized Block Design with three replications. The wheat crop was sown on November 21, 2014. Significant higher grain yield was recorded MP 4010 (4520 kg/ha). Application of 75\% RDF +5 tonnes FYM /ha had significant effect on higher grain yield than other levels of fertility. The yield contributing components like number of effective tillers per plant, Ear length, No. of grains, Test weight, Protein yield were significantly higher under $75 \%$ RDF +5 tonnes FYM /ha fertility levels. Harvest index and straw yield were not influenced significantly due to fertility levels and varieties. Thus it may be concluded that fertility levels of $75 \%$ $\mathrm{RDF}+5$ tonnes FYM /ha proved as the most suitable practice for exploitation of the yield potential of wheat. The variety MP 4010 was found most suitable for achieving higher yield of wheat.

\section{Introduction}

Wheat (Triticum aestivum L.) is the second most important cereal crop after rice in the context to its antiquity and its use as source of food and energy in India. Wheat crop has occupied almost 29.9 million hectares and producing 93.50 million tonnes in India. Improvement in wheat production can be achieved by enhancing through the development of new cultivars having wider genetic base and manage from integrated use of resources, as the land area under wheat is not expected to expand further. Balanced fertilizer through organic and inorganic sources improves the soil health as well as boosts the productivity of wheat. Organic matter is the substrate for a large number of soil living beneficial organisms which are essential to keep the plant healthy. Enriched FYM improves the nutrient availability and increases wheat yield. Organic matter in soil increases the water holding capacity, cation exchange capacity as well as improves the soil structure for better performance of microorganisms. The soil which enriched in organic matter has been found to respond better to the application of nitrogenous 
fertilizers (Subbiah and Bajaj, 1968). About $40 \%$ of cattle dung is available for manuring, rest being wasted or used as fuel (White, 1957). Thus, a good amount of organic waste is lost which is an important input for agricultural production. In the event of widespread energy crisis and deterioration of soil fertility due to intensive agriculture and imbalance use of fertilizers, it is highly desirable for making massive efforts to adopt organic matter recycling as a source of bioenergy and to supplement the demand gap of $\mathrm{N}, \mathrm{P}, \mathrm{K}$ as well as to enrich the soil in respect to micronutrients. Thus, the combination of FYM with inorganic fertilizers may be highly effective for increasing the yield under late sown wheat as well as better quality of produce in addition to sustaining biological health and maintaining balanced $\mathrm{C}: \mathrm{N}$ ratio of the soil. Thus present study was undertaken to assess the performance of wheat varieties under various fertility levels.

\section{Materials and Methods}

The field experiment was conducted at Research Farm, College of Agriculture, Gwalior, during Rabi season of 2014-15. The climate of the region is semi-arid and subtropical. The experimental area is located at $26^{\circ} 13^{\prime}$ North latitude and $78^{\circ} 14^{\prime}$ East longitude and 206 meters above sea mean level. The topography of the field was uniform with proper drainage. The soil of the experimental field was sandy clay loam.

Soil samples of the surface soil up to $15 \mathrm{~cm}$ depth were taken randomly before sowing and a composite sample made after mixing all these. The sample was analyzed for its various mechanical properties $(\mathrm{pH} 7.60$; EC 0.43 and organic matter $0.44 \%)$. Percentage of sand (59.50), silt (18.45), clay (22.05) and textural class (Sandy clay loam) was determined by International pipette method (Piper, 1950). Nitrogen, Phosphorus (P) and Potassium (K) in soil were applied in the form of urea (46\% $\mathrm{N})$, Single super-phosphate $\left(16 \% \mathrm{P}_{2} \mathrm{O}_{5}\right)$ and Murate of potash $\left(60 \% \mathrm{~K}_{2} \mathrm{O}\right)$, respectively. Recommended doses of NPK for wheat were 120:60:40 kg/ ha, respectively. Full quantities of $\mathrm{P}$ and $\mathrm{K}$ fertilizers and half quantity of $\mathrm{N}$ fertilizer were mixed together and placed about 3-4 $\mathrm{cm}$ below the seed in the furrow at the time of sowing. Well decomposed FYM was added to the plots as per treatment and mixed with last tillage operation. Further, half dose of nitrogen was applied as top dressing after first irrigation.

The experiment was laid out in Factorial Randomized Block Design with three replications. The net plot size measured $3.2 \mathrm{~m}$ x $2.6 \mathrm{~m}$. Before seed bed preparation, presoaking irrigation of $10 \mathrm{~cm}$ was applied. When soil reached at proper moisture level, the seed bed was prepared by giving four cultivations with a tractor mounted cultivator. Each time soil was cultivated to a depth of 8$10 \mathrm{~cm}$. Planking was given, after every two times cultivations. Seeds were sown as per treatments by funnel attached with desi plough, keeping row to row distance of $20 \mathrm{~cm}$. The crop was sown done on November 21, 2014. Weeds were kept under control by hand weeding. Observations were recorded on 5 plants of each genotypes for Plant height, Number of effective tillers per plant, Length of ear, Number of grains per ear, Test weight, Grain yield (kg/ha), Straw yield ( $\mathrm{kg} / \mathrm{ha})$, Protein yield(kg/ha), Dry weight per plant, crop growth rate and Harvest index.

\section{Statistical analysis}

The data were analyzed by using the analysis of variance technique (Fisher, 1958). When a significant "F" value was obtained for treatment effect, least significant differences (LSD) test at $0.05 \mathrm{P}$ was applied to determine the significance of the treatment means (Steel et al., 1997). 


\section{Results and Discussion}

\section{Plant height (cm)}

Plant height increased progressively at the successive stages of crop growth as influenced by various varieties and fertility levels. The plant height was influenced significantly due to different varieties and fertility levels at all growth stages. Plant height was significantly differed between varieties at all stages of crop growth except at 30 DAS. Data pertaining to plant height is summarized in table 1. In general, plant height increased successfully at 30, 60 and 90 DAS. There after the rate of increase in plant height was nominal at harvest stage of the crop. Maximum plant height was recorded variety MP-4010. Regarding Fertility levels, At 30 and 60 DAS, maximum plant height was recorded under application of $150 \%$ RDF followed by $125 \%$ and $75 \%$ RDF +5 tonnes FYM /ha and both these treatments were statistically at par with each other both stages. Same trend was found at 90 DAS and harvest stage. Variation in plant height among varieties might also be probably due to their genetic characters. Similar finding in respect to varieties were reported by Brijkishor (1998). The significant increase in plant height was recorded in present investigation, which was mainly due to more availability of fertility levels. Higher nitrogen level resulted higher nitrogen uptake, which ultimately results into increased protein synthesis, cell division and cell enlargement which express morphologically an increase in height of plant. Similar findings were reported by Mankotia et al., (2007).

\section{Dry weight per plant}

Data pertaining to dry weight per plant have been presented in table 2 . The data revealed that the dry weight per plant in general, increased by multifold with the increase of plant growth from 30 days stage up to the harvest stage. Varieties and fertility levels treatments influenced this parameter significantly at all the growth stages except at 30 days stage in case of varieties. Significant varietal differences were noticed for plant dry weight at different stages of growth. At 60 DAS to maturity, 'MP 4010' recorded the highest plant dry weight over RVW 4106.Application of $75 \% \mathrm{RDF}+5$ tonnes FYM /ha recorded maximum plant dry weight, which was significantly higher than all fertility level at 60, 90 DAS and maturity. However, it was statistically at par with treatment $150 \%$ RDF and $125 \%$ RDF. Minimum plant dry weight per plant was registered under application of $50 \% \mathrm{RDF}+10$ tonnes FYM /ha at all the stages.

\section{Number of effective tillers per plant}

The number of effective tillers per plant increased progressively at the successive stages of crop growth as influenced by varieties and fertility levels. Data pertaining to number of tillers per plant have been summarized in table 3 . The higher number of tillers per plant was recorded with variety MP 4010, which was at par with variety RVW 4106 and significantly superior varieties. Among the fertility levels, 75\% RDF with 5 tonnes FYM /ha performed the best producing maximum number of effective tillers followed by $125 \% \mathrm{RDF}$ and $150 \% \mathrm{RDF}$, and all these treatments were at par with each other and significantly higher over the other fertility levels.

The significantly lowest numbers of effective tillers were noted under application of $50 \%$ $\mathrm{RDF}+10$ tonnes FYM /ha which was comparable to $100 \%$ RDF. Variation in number of tillers might be due to their own genetic characteristics. Similar finding in respect to varieties were reported by Behra (1994) and Singh (1998). The significant increase in number of tillers per meter row 
length was recorded only upto $150 \mathrm{~kg} \mathrm{~N}$. Similar results were reported by Gontia and Joshi (2000) and Avijit et al., (2003).

\section{Length of ear (cm)}

The length of ear influenced significantly by varieties and fertility levels. The maximum length of ear was recorded with variety MP 4010, which was at par significantly superior of the varieties. As regards fertility levels, maximum ear length was recorded with $75 \%$ RDF with 5 tonnes FYM /ha which was found superior over rest of other fertility levels.

\section{No. of grains per ear}

The number of grains per ear influenced significantly by varieties and fertility levels. The maximum number of grains per ear was found with variety MP 4010, which was at par with significantly superior with RVW 4106 variety. In case of fertility levels, significant difference in number of grains per ear was observed for different fertility levels. Fertility level $75 \%$ RDF + 5 tonnes FYM /ha produced maximum number of grains per ear followed by $125 \% \mathrm{RDF}$ and $150 \% \mathrm{RDF}$ and all these treatments found statistically at par with each other.

\section{Test weight (g)}

Data pertaining to test weight have been presented in table 2 . The data revealed that the test weight (g) was significantly by varieties as well as fertility levels. Different cultivars tested during experimentation could reach to the level of significance in increasing the test weight. However, the higher value of test weight (37.11) was obtained with the MP 4010. However, the higher test weight of $38.47 \mathrm{~g}$ was recorded with the application of $75 \% \mathrm{RDF}+5$ tonnes FYM /ha. Yield was the resultant of co-ordination of yield attributes. Vigorously growing plants are able to absorb larger quantity of mineral nutrients through well-developed root system.

Table.1 Effect of different treatments on plant height at various growth stages of the wheat

\begin{tabular}{|c|c|c|c|c|}
\hline \multirow[t]{2}{*}{ Treatments } & \multicolumn{4}{|c|}{ Plant height (cm) } \\
\hline & 30 DAS & $60 \mathrm{DAS}$ & 90 DAS & Harvest \\
\hline \multicolumn{5}{|l|}{ Varieties } \\
\hline RVW 4106 & 12.85 & 52.01 & 85.83 & 86.11 \\
\hline MP 4010 & 13.11 & 52.97 & 87.80 & 88.11 \\
\hline SEm \pm & 0.11 & 0.29 & 0.31 & 0.30 \\
\hline CD (0.05) & NS & 0.82 & 0.85 & 0.84 \\
\hline \multicolumn{5}{|l|}{ Fertility levels } \\
\hline $\begin{array}{l}50 \% \text { RDF + } 10 \text { tonnes } \\
\text { FYM /ha }\end{array}$ & 11.81 & 49.58 & 83.12 & 83.42 \\
\hline $\begin{array}{l}\text { 75\% RDF + } 5 \text { tonnes FYM } \\
\text { /ha }\end{array}$ & 13.37 & 53.73 & 88.12 & 88.42 \\
\hline $100 \%$ RDF & 12.81 & 51.47 & 85.85 & 86.16 \\
\hline $125 \%$ RDF & 13.45 & 53.83 & 88.33 & 88.63 \\
\hline $150 \%$ RDF & 13.46 & 53.84 & 88.64 & 88.92 \\
\hline SEm \pm & 0.13 & 0.46 & 0.48 & 0.38 \\
\hline CD (0.05) & 0.37 & 1.29 & 1.34 & 1.33 \\
\hline
\end{tabular}


Table.2 Crop growth stages of different treatments on dry weight of wheat crop

\begin{tabular}{|c|c|c|c|c|}
\hline \multirow[t]{2}{*}{ Treatments } & \multicolumn{4}{|c|}{ Dry weight (g/plant) } \\
\hline & 30 DAS & 60 DAS & 90 DAS & Harvest \\
\hline \multicolumn{5}{|l|}{ Varieties } \\
\hline RVW 4106 & 1.23 & 4.47 & 8.41 & 9.29 \\
\hline MP 4010 & 1.23 & 4.56 & 8.62 & 9.60 \\
\hline S.E. $\mathbf{m} \pm$ & 0.01 & 0.03 & 0.07 & 0.09 \\
\hline C.D. $(0.05$ & NS & 0.08 & 0.19 & 0.24 \\
\hline \multicolumn{5}{|l|}{ Fertility levels } \\
\hline $\begin{array}{l}\text { 50\% RDF + } 10 \text { tonnes FYM } \\
\text { /ha }\end{array}$ & 1.20 & 4.14 & 7.54 & 8.38 \\
\hline $\begin{array}{l}\text { 75\% RDF + } 5 \text { tonnes FYM } \\
\text { /ha }\end{array}$ & 1.27 & 4.92 & 9.59 & 10.63 \\
\hline $100 \%$ RDF & 1.20 & 4.26 & 7.98 & 8.87 \\
\hline $125 \%$ RDF & 1.24 & 4.74 & 9.03 & 9.97 \\
\hline $150 \%$ RDF & 1.24 & 4.53 & 8.43 & 9.36 \\
\hline S.E. $\mathrm{m} \pm$ & 0.01 & 0.06 & 0.11 & 0.13 \\
\hline C.D. (0.05) & 0.3 & 0.13 & 0.31 & 0.37 \\
\hline
\end{tabular}

Table.3 Effect of different treatments on yield contributing characters of wheat crop

\begin{tabular}{|c|c|c|c|c|c|}
\hline Treatments & $\begin{array}{c}\text { No. of } \\
\text { effective } \\
\text { tillers/plant }\end{array}$ & $\begin{array}{c}\text { Ear } \\
\text { length } \\
(\mathrm{cm})\end{array}$ & $\begin{array}{l}\text { No. of } \\
\text { grains /ear }\end{array}$ & $\begin{array}{l}\text { Test weight } \\
\text { (g) }\end{array}$ & $\begin{array}{l}\text { Protein } \\
\text { yield } \\
\text { (kg/ha) }\end{array}$ \\
\hline \multicolumn{6}{|l|}{ Varieties } \\
\hline RVW 4106 & 3.74 & 7.58 & 40.27 & 36.57 & 504.35 \\
\hline MP 4010 & 3.88 & 7.64 & 41.44 & 37.11 & 515.33 \\
\hline SE $\mathbf{m \pm}$ & 0.04 & 0.04 & 0.27 & 0.11 & 3.86 \\
\hline CD (0.05) & 0.12 & NS & 0.76 & 0.29 & 10.71 \\
\hline \multicolumn{6}{|l|}{ Fertility levels } \\
\hline $\begin{array}{l}50 \% \text { RDF + } 10 \text { tonnes } \\
\text { FYM /ha }\end{array}$ & 3.10 & 7.07 & 39.94 & 34.58 & 460.77 \\
\hline $\begin{array}{l}75 \% \text { RDF }+5 \text { tonnes } \\
\text { FYM /ha }\end{array}$ & 4.30 & 7.95 & 41.61 & 38.47 & 546.10 \\
\hline $100 \%$ RDF & 3.18 & 7.63 & 40.28 & 34.98 & 494.79 \\
\hline $125 \%$ RDF & 4.26 & 7.69 & 41.44 & 38.12 & 524.40 \\
\hline $150 \%$ RDF & 4.22 & 7.71 & 41.00 & 38.06 & 523.13 \\
\hline SEm & 0.07 & 0.06 & 0.43 & 0.17 & 6.11 \\
\hline CD $(0.05)$ & 0.19 & 0.17 & 1.20 & 0.46 & 16.93 \\
\hline
\end{tabular}


Table.4 Effect of different treatments on yield contributing characters of wheat crop

\begin{tabular}{|c|c|c|c|c|}
\hline Treatments & $\begin{array}{l}\text { Grain yield } \\
\text { (kg/ha) }\end{array}$ & $\begin{array}{l}\text { Straw yield } \\
\text { (kg/ha) }\end{array}$ & $\begin{array}{c}\text { Biological yield } \\
\text { (kg/ha) }\end{array}$ & $\begin{array}{c}\text { Harvest index } \\
(\%)\end{array}$ \\
\hline \multicolumn{5}{|l|}{ Varieties } \\
\hline RVW 4106 & 4456 & 6717 & 11173 & 39.86 \\
\hline MP 4010 & 4520 & 6720 & 11240 & 40.21 \\
\hline SEm \pm & 16 & 37 & 40 & 0.16 \\
\hline $\mathrm{CD}(0.05)$ & 35 & NS & NS & NS \\
\hline \multicolumn{5}{|l|}{ Fertility levels } \\
\hline 50\% RDF + 10 tonnes FYM /ha & 4131 & 6282 & 10413 & 39.64 \\
\hline 75\% RDF + 5 tonnes FYM /ha & 4685 & 6872 & 11557 & 40.54 \\
\hline $100 \%$ RDF & 4421 & 6646 & 11067 & 39.95 \\
\hline $125 \%$ RDF & 4604 & 6791 & 11395 & 40.39 \\
\hline $150 \%$ RDF & 4599 & 7002 & 11601 & 39.66 \\
\hline SEm \pm & 26 & 58 & 63 & 0.25 \\
\hline \multirow[t]{2}{*}{ CD (0.05) } & 71 & 160 & 174 & 0.69 \\
\hline & $\mathrm{S}$ & NS & $\mathbf{S}$ & NS \\
\hline
\end{tabular}

Table.5 Effect of different treatments on crop growth rate (CGR) at various growth stages of the wheat crop

\begin{tabular}{|l|c|c|c|c|}
\hline \multirow{2}{*}{ Treatments } & \multicolumn{4}{|c|}{ CGR $\left(\mathrm{g} / \mathrm{m}^{2} /\right.$ days $)$ at } \\
\hline Varieties & 30 DAS & $\mathbf{6 0}$ DAS & 90 DAS & Harvest \\
\hline RVW 4106 & 8.21 & 21.59 & 26.27 & 5.67 \\
\hline MIP 4010 & 8.21 & 22.21 & 27.04 & 6.31 \\
\hline S.E. m \pm & $\mathbf{0 . 0 4}$ & $\mathbf{0 . 2 0}$ & $\mathbf{0 . 5 1}$ & $\mathbf{0 . 1 9}$ \\
C.D. (0.05) & NS & $\mathbf{0 . 5 6}$ & NS & $\mathbf{0 . 5 3}$ \\
\hline Fertility levels & & & & \\
\hline 50\% RDF + 10 tonnes FYM /ha & 8.00 & 19.57 & 22.72 & 5.40 \\
\hline 75\% RDF + 5 tonnes FYM /ha & 8.45 & 24.33 & 31.15 & 6.75 \\
\hline 100\% RDF & 8.01 & 20.40 & 24.77 & 5.74 \\
\hline 125\% RDF & 8.28 & 23.32 & 28.60 & 6.06 \\
\hline 150\% RDF & 8.29 & 21.88 & 26.05 & 5.99 \\
\hline S.E. m \pm & $\mathbf{0 . 0 6}$ & $\mathbf{0 . 3 2}$ & $\mathbf{0 . 8 0}$ & $\mathbf{0 . 3 0}$ \\
\hline C.D. (0.05) & $\mathbf{0 . 1 8}$ & $\mathbf{0 . 8 9}$ & $\mathbf{2 . 2 2}$ & $\mathbf{0 . 8 3}$ \\
\hline
\end{tabular}

\section{Yield parameters}

\section{Yield grain yield (Kg / ha)}

The data pertaining to grain yield were recorded and presented in table 4 . The data revealed that the grain yield influenced significantly by varieties along with fertility levels. Among the varieties, maximum grain yield was recorded with variety MP 4010, which was significantly superior over RVW 4106 variety. In case of fertility levels, grain 
yield /ha was significantly influenced due to different fertility levels. The maximum grain yield was noted with $75 \% \mathrm{RDF}+5$ tonnes FYM /ha and it was significantly higher over rest of fertility levels. This might be due to number of grains per ear, grain weight per ear and test weight. Similar findings were reported by Singh et al., (2003).

\section{Straw yield (kg/ ha)}

The data presented in table 4 reveals the different fertility treatments were significantly affected straw yield $(\mathrm{kg} / \mathrm{ha})$ but not due to varieties. Among fertility levels, the maximum straw yield was noted with $150 \%$ RDF and it was significantly higher over other fertility. Straw yield increased significantly with increasing fertility levels $150 \%$ RDF. Further increase in $150 \%$ RDF levels up to did not bring significant increase in straw yield. This may be probably due to higher shoots and increased rate of dry matter accumulation. Similar results were given by Singh (2002).

\section{Biological yield (kg / ha)}

The biological yield was deviated significantly due to fertility levels. However, between varieties, MP 4010 gave significantly higher biological yield compared to RVW 4106. As regarding fertility levels, the maximum biological yield was obtained with application of $75 \%$ RDF +5 tonnes FYM /ha followed by $150 \% \mathrm{RDF}$ and $125 \% \mathrm{RDF}$ and these treatments were at par with each other and significantly higher over rest of the other treatments.

\section{Harvest index (\%)}

Harvest index as influenced by both varieties and fertility levels (Table 4). Harvest index indicate the relationship between economical yield and biological yield. The data reveals that varieties and fertility levels not influenced significantly. The maximum harvest index was recorded with varieties MP 4010 during experimentation. Regarding fertility levels it was highest (40.54) with $75 \% \mathrm{RDF}+5$ tonnes FYM /ha and minimum (39.64) with $50 \%$ RDF + 10 tonnes FYM /ha. Harvest index of wheat was not affected significantly due to fertility levels. Similar results were given by Singh (1998). The highest grain and straw yield was recorded with variety MP 4010. The reason behind this may be because of good plant stand, more number of ear bearing tillers, long ear head and more number of grains per ear with more test weight. Similar findings were obtained by Singh (1998) and Shiv et al., (2017). The varieties did not differ significantly in harvest index.

\section{Crop growth rate (CGR)}

The crop growth rate influenced significantly by varieties and fertility levels. The scrutiny of data in Table 5 revealed that in general, CGR was increased with the increase in plant growth from 30 DAS to 90 DAS stage. Thereafter it tended to decline up to maturity stage under the various treatments. Among fertility levels, maximum value of CGR was obtained under $75 \%$ RDF + 5 tonnes FYM/ha treatment at all the stages of observation. Minimum value of CGR was registered with $50 \% \mathrm{RDF}+10$ tonnes $\mathrm{FYM} / \mathrm{ha}$ at all the stages.

\section{Quality parameter}

\section{Protein yield}

The table revealed that protein yield was significantly influenced by varieties and fertility levels. A perusal of data in table 3 revealed that maximum protein yield content was recorded significantly higher protein yield was registered with variety MP 4010 
compared to variety RVW 4106. Regarding fertility levels, protein yield was influenced significantly. The maximum Protein yield was recorded under the application of $75 \% \mathrm{RDF}+$ 5 tonnes FYM /ha, which was significantly higher compared to remaining fertility levels (Memon and Jamro, 1988).

\section{Acknowledgement}

The authors wish to thanks the Head, Department of Agronomy, Collage of Agriculture, Gwalior, for providing facilities and support for this research activity.

\section{References}

Avijit, S., Pandey, M.D., Sharma, S.N., Singh, R.K., Kumar, A., Prakash, S., Srivastava, V.K. and Shukla, P. 2003. Surface seeding of wheat (Triticum aestivum L.) as affected by seed rate and nitrogen level. Indian $J$. Agril. Sci., 73(9): 509-511.

Behra, A.K. 1994. Response of wheat (Triticum aestivum L.) varieties to date of sowing. Indian J. Agron., 31(1): 171-173.

Brijkishor. 1998. To assess the performance of newly developed strains of wheat under zero tillage condition with varying nitrogen levels. M.Sc. Ag.) Thesis submitted to N.D.U.A \& T., Kumarganj, Faizabad.

Fisher, R.A. 1958. Statistical method for research workers. Oliver and Boyd, Edinburgh

Gontia, A.S. and Joshi, A. 2000. Effect of varying population densities and nitrogen levels on yield and yield attributes of wheat. Crop Res., 19(2): 184-188.

Kumpawat, B.S. and Rathore S.S. 2003. Effect of preceding grain legumes on growth, yield, nutrient content and uptake by wheat (Triticum aestivum L.) under different nitrogen levels. Crop-research-Hisar, 25(2): 209-214.

Mankotia, K., Savic, N., Jelic, J. and Nikoic, K. 2007. The influence of mineral nitrogen on plant height and spike length at various cultivars of winter wheat. Faculty of agriculture, University of Prishtin, Lesak, Serbia. 58(2): 37-42.

Memon, G. H and Jamro, G. H. 1988 Influence of nitrogen fertilizer on grain protein content and NPK content of straw in late sown wheat. J Scientific Industrial Res 9: 649-50.

Piper, C.S. 1950. Soil and plant analysis. Adelaide University of Adelaide pp, 223-227 and 7779.

Shiv V. S., Avanish Kumar Singh, Nikhil Raghuvanshi and Singh, R.A. 2017. Effect of Nitrogen Management Practices on the Productivity of Late Sown Wheat (Triticum aestivum L.) Varieties. Int.J. Curr. Microbiol. App. Sci. 6 (7): 878-887.

Singh, A.N. 2002. Response of wheat varieties to various nitrogen levels. M.Sc. Ag. b) thesis submitted to NDUA\&T, Kumarganj, Faizabad, (U.P.), India.

Singh, B. 1998. To assess the performance of new wheat varieties under late-sown condition with different nitrogen levels. M.Sc. (Ag) thesis submitted to N.D.U.A.\& T., Kumarganj, Faizabad.

Steel, R. G. D., Torrie J. H. and Dickey, D. A. 1997. Principles and procedures of statistics: A biometrical approach. 3rd ed. McGraw Hill Book Co. Inc. New York: 400-428.

Subbiah, B.V. and Bajaj, J.C. 1968. Association of certain soil factors with higher paddy yields. J. Indian Soc. Soil Sci., 16(3): 297300 .

White, R.O. 1957. The grassland and fodder resources in India. Scientific monograph, no. 22, ICAR: 1-47.

\section{How to cite this article:}

Rai Anil Kumar, Sunil Kumar Jatav and Dixit, J.P. 2018. To Assess the Performance of Wheat Varieties under Various Fertility Levels. Int.J.Curr.Microbiol.App.Sci. 7(10): 1839-1846. doi: https://doi.org/10.20546/ijcmas.2018.710.211 